\title{
ESTIMATING PEACH PALM FRUIT SURFACE AREA USING ALLOMETRIC RELATIONSHIPS
}

\author{
Marilene Leão Alves Bovi*; Sandra Heiden Spiering \\ IAC, C.P. 28 - CEP: 13001-970- Campinas, SP. \\ *Corresponding author<mlabovi@cec.iac.br>
}

\begin{abstract}
Fruit surface area is an important trait in studies of developmental physiology, as well as in entomological and phytopathological research, where damage caused by insects and/or microorganisms needs to be quantified. Nonetheless, direct measurement of this trait is difficult, not very precise and destructive. This study establishes allometric relationships to estimate the surface area of peach palm (Bactris gasipaes Kunth, Palmae) fruits. Five fruits were harvested, at different maturation stages, from each of 18 plants. Image digitalization and edition methodology was adapted and compared with the traditional gravimetric method. Regression analysis and curve fitting were used to compare the two methods and establish allometric relationships among fruit surface area and fruit weight and size. The method based on image digitalization was twice as fast as the gravimetric method. Curve fitting for all pairs of independent and dependent variables was better with the image method. For most relationships, the best model was the exponential function $(Y=$ $\left.a x^{b}\right)$, although, due to its simplicity, the linear model is also adequated. The best allometric estimates of fruit surface area $(Y)$ were obtained using the product of fruit length by maximum width $(x)$ were: $Y=2.077 x^{1.189}$ $\left(R^{2}=94.8 \%\right)$; and $Y=-6.261+3.961 \times\left(R^{2}=94.5 \%\right)$. Traits needed to establish this relationship are easily measured and non-destructive in nature. Validation of the allometric equations is essential when applied to other populations or landraces.
\end{abstract}

Key words: Bactris gasipaes, pejibaye, area estimation, curve fitting

\section{ESTIMATIVA DA ÁREA SUPERFICIAL DE FRUTOS DE PUPUNHEIRA POR RELAÇÕES ALOMÉTRICAS}

\begin{abstract}
RESUMO: A área superficial do fruto é de importância fundamental em estudos relacionados à fisiologia do desenvolvimento, bem como em pesquisas entomológicas e fitopatológicas, onde o dano causado por insetos e/ou microorganismos precisa ser quantificado. No entanto, a medição direta dessa característica é difícil, além de não muito precisa e destrutiva. Neste estudo foram estabelecidas relações alométricas visando estimar a área superficial de frutos de pupunheira (Bactris gasipaes Kunth). Foram colhidos cinco frutos por planta, em diferentes estádios de maturação, de 18 plantas matrizes. A metodologia baseada em digitalização e edição de imagens foi adequada ao presente estudo e comparada com o método gravimétrico. Com base em análise de regressão e ajuste de curvas, os dois métodos foram comparados, determinando-se ainda relações alométricas entre área superficial e peso e dimensões do fruto. O método de digitalização de imagens mostrou-se duas vezes mais rápido que o gravimétrico, obtendo-se bom ajuste para todos os pares testados. Para a maioria das relações estabelecidas o modelo de melhor ajuste foi a potência da variável independente $(\mathrm{Y}=\mathrm{ax})$. No entanto, pela simplicidade, recomenda-se também o modelo linear. Para a variável $(\mathrm{x})$ obtida pela multiplicação do comprimento e largura máxima do fruto, as equações que permitiram estimar a área superficial ( $Y$ ) foram: $Y=2,077 \times{ }^{1,189}\left(R^{2}=94,8 \%\right)$; e $Y=-6,261+3,961 \times\left(R^{2}=94,5 \%\right)$. As características necessárias para a estimativa são de fácil mensuração e apresentam caráter não destrutivo. Essas equações requerem validação quando usadas em outras populações ou raças.

Palavras-chave: Bactris gasipaes, pupunha, estimativa de área, ajuste de curvas
\end{abstract}

\section{INTRODUCTION}

The determination of the surface area of fruits is necessary to quantify damage caused by insects and microorganisms (Meah, 1993; Yang et al., 1997; Padmanaban et al., 1997; Timmer et al., 1998). Surface area is also important to establish the relations, in different maturity stages, between photosynthetic activity and fruit development (Banarar, et al., 1994; Lister et al., 1994; Marcelis \& Hofmaneijer, 1995; Dias-Perez, 1998). The direct measurement of fruit surface area, is important in these studies, but difficult, not very precise and usually destructive (Anadaraj \& Bhagavan 1983; Clayton et al., 1995).

Methods based on planimetry, gravimetry and geometry may be applied in order to establish allometric relationships between the surface area of fruits and some simple measurements, such as fruit length, width (diameter) or weight (mass) (Galbreath, 1976; Anabaraj \& Bhagavan, 1983; Clayton et al., 1995; Schultz, 1995). The recent use of scanners, image edition and analysis, supported by specific software, allows for fast estimation of those measurements in both, fruits and leaves, with high precision (Caldas et al., 1992). 
In the present study a method was developed to estimate the surface area of pejibaye fruits (Bactris gasipaes Kunth, Palmae) through image digitalization and analysis and was compared with the gravimetric method. Simple allometric relationships were studied in order to estimate fruit surface area using length, width, weight and cross-section.

\section{MATERIAL AND METHODS}

Fruits at different maturity stages were harvested from 18 plants (5 fruits/plant), selected at random from the Belém hybrid population, which contains a mixture of Pará microcarpa, Solimões mesocarpa and Putumayo macrocarpa landraces (MoraUrpí et al., 1993), cultivated in Mococa, SP, Brazil, $\left(21^{\circ} 28^{\prime} \mathrm{S}, 47^{\circ} 00^{\prime} \mathrm{W}, 665 \mathrm{~m}\right)$. The objective of the study was to develop allometric relationships to support developmental physiology studies. Samples were choosen to be as variable as possible (Table 1), being composed of material in the initial development stage (plants 17 and 18), parthenocarpic fruits in the initial stage (plants 11 to 13), immature fertile fruit stage (plants 10, 14, 15 and 16), and mature fertile fruits (plants 1 to 9 ).

Whole fruits (fruit with calyx and corolla) were measured in length and maximum width with a hand caliper. The length/width ratio was calculated, which gives an idea of the fruit shape. After that, fruits were weighted, cut longitudinally in half, and the seeds removed. The outline of the halved fruits was traced on paper, according to Clement (1986a). This cross-sectional area was estimated digitally, and also calculated as the product of length by width.

Table 1 - Mean dimensions and color of fertile (1-9) and parthenocarpic (10-18) fruits and seeds from peach palms (Bactris gasipaes) harvested in Mococa, SP, in 1999.

\begin{tabular}{|c|c|c|c|c|c|c|c|c|c|c|c|}
\hline \multirow[b]{2}{*}{ Plant } & \multicolumn{8}{|c|}{ Fruit characteristics } & \multicolumn{3}{|c|}{ Seed characteristics } \\
\hline & Length & Width & $\begin{array}{l}\text { Shape } \\
\text { factor }^{1}\end{array}$ & Weight & $\begin{array}{l}\text { Cross- } \\
\text { sectional } \\
\text { area }^{2}\end{array}$ & $\begin{array}{c}\text { Surface } \\
\text { area }^{2}\end{array}$ & Fruit color & Pulp color & Length & Width & Weight \\
\hline & --------- cm & n ---------- & & $g$ & --------- cm & $\mathrm{m}^{2}$---------- & & & --------- cn & m ---------- & g \\
\hline 1 & $4.85 a b$ & $5.02 \mathrm{a}$ & $0.97 \mathrm{k}$ & $72.14 \mathrm{a}$ & 20.32 a & $95.14 \mathrm{a}$ & $\begin{array}{l}\text { Greenish } \\
\text { orange }\end{array}$ & Light orange & $2.01 \mathrm{ab}$ & $1.61 \mathrm{abc}$ & $2.92 b$ \\
\hline 2 & $4.96 \mathrm{a}$ & $4.68 \mathrm{~b}$ & $1.06 \mathrm{ijk}$ & $65.94 \mathrm{a}$ & $19.35 a b$ & $92.29 \mathrm{a}$ & $\begin{array}{l}\text { Greenish } \\
\text { orange }\end{array}$ & Light orange & $2.27 \mathrm{a}$ & $1.70 a b$ & $3.73 \mathrm{a}$ \\
\hline 3 & $4.86 \mathrm{ab}$ & $4.29 \mathrm{~cd}$ & $1.13 \mathrm{hij}$ & $50.86 \mathrm{~b}$ & $17.52 \mathrm{bc}$ & $73.60 \mathrm{~b}$ & $\begin{array}{l}\text { Yellowish } \\
\text { red }\end{array}$ & Light orange & $1.75 b$ & $1.45 \mathrm{bc}$ & $2.10 \mathrm{c}$ \\
\hline 4 & $4.63 \mathrm{abc}$ & $4.34 \mathrm{c}$ & 1.07 ijk & $51.27 b$ & $17.24 \mathrm{c}$ & $70.76 \mathrm{~b}$ & $\begin{array}{l}\text { Greenish } \\
\text { yellow }\end{array}$ & Light yellow & $1.98 \mathrm{ab}$ & $1.72 \mathrm{a}$ & $2.11 \mathrm{C}$ \\
\hline 5 & $4.73 a b c$ & $4.04 \mathrm{de}$ & 1.17 ghij & $44.24 \mathrm{~b}$ & $16.18 \mathrm{~cd}$ & $70.14 b$ & $\begin{array}{l}\text { Dark } \\
\text { orange }\end{array}$ & Light orange & $2.29 \mathrm{a}$ & $1.50 \mathrm{abc}$ & $2.48 \mathrm{bc}$ \\
\hline 6 & $4.73 \mathrm{abc}$ & $4.19 \mathrm{~cd}$ & $1.13 \mathrm{hij}$ & $47.59 \mathrm{~b}$ & $16.71 \mathrm{~cd}$ & $67.14 \mathrm{bc}$ & Light red & Orange & $1.75 b$ & $1.43 \mathrm{c}$ & $2.05 \mathrm{c}$ \\
\hline 7 & $4.47 \mathrm{bc}$ & $3.70 \mathrm{f}$ & $1.21 \mathrm{fgh}$ & $36.03 \mathrm{c}$ & $14.40 \mathrm{de}$ & $60.29 \mathrm{bcd}$ & Light red & Light orange & $1.89 \mathrm{ab}$ & $1.44 \mathrm{c}$ & $2.14 \mathrm{c}$ \\
\hline 8 & $3.98 \mathrm{de}$ & $3.53 f$ & $1.13 \mathrm{hij}$ & $28.75 \mathrm{~cd}$ & $12.43 \mathrm{f}$ & $51.40 \mathrm{de}$ & Red & Light orange & $1.77 \mathrm{~b}$ & $1.51 \mathrm{abc}$ & $2.45 \mathrm{bc}$ \\
\hline 9 & $3.42 \mathrm{fg}$ & $3.49 f$ & $0.98 \mathrm{k}$ & $23.84 \mathrm{de}$ & $10.33 \mathrm{~g}$ & 38.02 ef & Yellow & Light orange & $1.86 \mathrm{ab}$ & $1.38 \mathrm{c}$ & $1.87 \mathrm{C}$ \\
\hline 10 & $4.39 \mathrm{bc}$ & $3.51 \mathrm{f}$ & 1.25 efgh & $31.62 \mathrm{c}$ & 13.29 ef & $51.57 \mathrm{de}$ & Green & Light yellow & 0.22 c & $0.18 d$ & $0.07 d$ \\
\hline 11 & $4.54 a b$ & 3.77 ef & $1.20 \mathrm{fghi}$ & $35.14 \mathrm{c}$ & 14.21 ef & $67.38 \mathrm{bc}$ & $\begin{array}{l}\text { Greenish } \\
\text { orange }\end{array}$ & Light yellow & - & - & - \\
\hline 12 & $4.64 \mathrm{abc}$ & $3.62 \mathrm{f}$ & $1.28 \mathrm{defg}$ & $34.89 c$ & 14.28 def & $54.71 \mathrm{~cd}$ & $\begin{array}{l}\text { Yellowish } \\
\text { green }\end{array}$ & Light yellow & - & - & - \\
\hline 13 & 3.78 ef & $2.64 \mathrm{~g}$ & $1.43 \mathrm{bc}$ & 16.48 def & $9.44 \mathrm{~g}$ & $32.72 \mathrm{f}$ & $\begin{array}{l}\text { Orangish } \\
\text { green }\end{array}$ & Yellow & - & - & - \\
\hline 14 & $4.35 \mathrm{~cd}$ & $2.64 \mathrm{~g}$ & $1.64 \mathrm{a}$ & $18.10 \mathrm{de}$ & $10.23 \mathrm{~g}$ & $35.40 \mathrm{f}$ & Green & White & - & - & - \\
\hline 15 & $3.24 \mathrm{~g}$ & $2.44 \mathrm{~g}$ & 1.33 cdef & 12.01 ef & $7.45 \mathrm{~h}$ & $25.51 \mathrm{~g}$ & Green & Light yellow & - & - & - \\
\hline 16 & $3.22 \mathrm{~g}$ & $2.36 \mathrm{~g}$ & 1.37 bcde & $8.95 \mathrm{fg}$ & $6.57 \mathrm{~h}$ & $24.65 f$ & Green & White & - & - & - \\
\hline 17 & $2.20 \mathrm{~h}$ & $1.50 \mathrm{~h}$ & $1.48 b$ & $2.53 \mathrm{~g}$ & 3.231 & $8.74 \mathrm{~g}$ & Green & White & - & - & - \\
\hline 18 & $1.78 \mathrm{~h}$ & $1.27 \mathrm{~h}$ & $1.41 \mathrm{bcd}$ & $1.66 \mathrm{~g}$ & $2.65 \mathrm{i}$ & $5.51 \mathrm{~g}$ & Green & White & - & - & - \\
\hline $\begin{array}{l}\text { CV } \\
(\%)\end{array}$ & 22.85 & 30.34 & 43.95 & 62.65 & 40.97 & 20.38 & & & 100.68 & 99.59 & 106.90 \\
\hline
\end{tabular}

${ }^{1}$ Fruit shape is the ratio length/width; ${ }^{2}$ Cross-sectional and surface areas obtained by the digitalization method. Means followed by the same letter in the vertical don't differ at $5 \%$ by Tukey test. 
The fruit mesocarp was evenly removed, close to the epicarp, with a teaspoon. Due to the variation in fruit maturity, 1 to $3 \mathrm{~mm}$ of pulp was left below the epicarp to permit handling, as the peach palm fruit epicarp is extremely thin. Three (in small fruits) to five (in large fruits) longitudinal cuts were made on the fruit peel (epicarp and uniform layer of pulp) to allow flattening of the fruit epicarp between sheets of transparent plastic to avoid damage to the scanner and improve image quality. The two halves of each fruit were digitalized at the same time, using a black and white image, and a scanner resolution of $300 \mathrm{dpi}$.

The images were processed with Corel PhotoPaint ${ }^{\oplus}$ to eliminate non-fruit peel bits. The fruit surface area was calculated with the software Area, version 2.1, (Caldas et al., 1992). The software is based on pixel counts of the images generated by the scanner, corrected with an appropriate calibration factor.

After digitalization, the fruit peels were weighed and disks of $0.393 \mathrm{~cm}^{2}$ were taken along the fruit surface (epicarp and 1 to $3 \mathrm{~mm}$ of pulp) with a cylindrical corker. The disks, varying from 2 to 19 depending on fruit size, were weighted and fruit surface area calculated using the gravimetric approach (Anadaraj \& Bhagavan, 1983). The time spent to estimate surface area for both methods was measured.

Allometric relationships between the variables measured and the two estimates of the surface area were calculated through curve fitting with the aid of CurveExpert, version 1.3 (Hyams, 1997). The best fitting equations were selected, based on their significance and the determination coefficient (Gomes, 1987), and the simplicity of the models (few parameters, easily calculated, without log transformation). Data transformation was not necessary. Simple correlations between the measured or estimated characteristics were obtained by the Pearson's method, at the $0.01 \%$ probability level.

\section{RESULTS AND DISCUSSION}

\section{Sample characterization}

Individual fruits ranged from 1.16 to $5.15 \mathrm{~cm}$ in width, from 1.70 to $5.26 \mathrm{~cm}$ in length, and from 1.5 (immature fruits) to $78.2 \mathrm{~g}$ in weight, with mean values slightly less extreme (Table 1). Epicarp color varied from light yellow to intense red, with green being the predominant color of immature and parthenocarpic fruits. The more mature the fruit, the easier the preparation of its exocarp for digitalization.

All the measured or estimated characteristics showed positive and highly significant $(0.01 \%)$ pairwise correlation coefficients, except for the pairs involving the length/width ratio, for which the correlations were significant and negative (Table 2). Parthenocarpic fruits generally had larger length/width ratio than fertile fruits, except for the fertile fruits from plant 7 which had a length/width ratio within the range of parthenocarpic fruits (Table 1).

\section{Comparison between methods}

The linear regression between the measurements obtained by the gravimetric and the image digitalization methods (Figure 1) indicates, a close correlation between them $(r=0.99)$ (Table 2). The largest data dispersion occurred in the 40 to $80 \mathrm{~cm}^{2}$ surface area interval, although the reasons for this were unclear. The coefficient of variation (CV) for estimates obtained by image digitalization (20.38\%) was lower than the one obtained by the gravimetric approach $(21.34 \%)$, thus the former was used in the establishment of allometric relationships presented below. A good relationship between these methods was reported previously for leaf area estimates of two Eucalyptus species (Caldas et al., 1992).

\section{Allometric relationships between fruit surface area and dimensions}

Allometric relations between fruit surface area and fruit length or maximum width provided equations with $\mathrm{R}^{2}=82.5 \%$ and $92.9 \%$, respectively (Table 3 ), suggesting that more than one dimension may be needed to obtain a better allometric relationship among these characteristics. The exponential function of fruit maximum width is complex (Table 3), but deserves consideration in developmental physiology studies, because fruit surface area can be estimated with only one measurement, taken easily, non-destructively, with a caliper. However, as maximum width is the major component of fruit shape, which is a population characteristic (Clement, 1986b), this equation must be validated for each new population.

Slightly better equations were obtained using the product of length by width (Table 3 ). Both models yielded high determination coefficients. The exponential function was better $\left(R^{2}=94.8 \%\right)$, but simpler and nearly as significant as the linear equation $\left(R^{2}=94.5 \%\right)$.

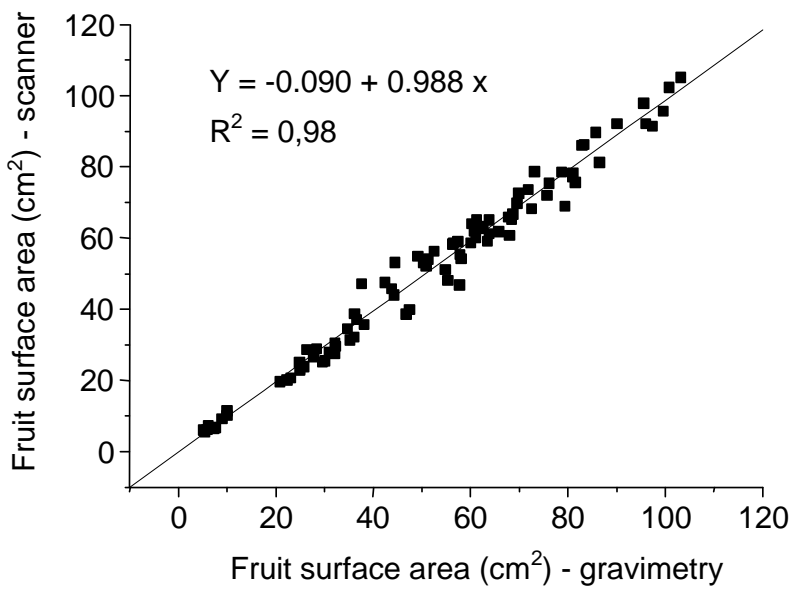

Figure 1 - Relationship between peach palm fruit surface area estimated by the digitalization and the gravimetric methods. 
Table 2 - Pearson's correlation coefficients $(r)$ between measured and estimated characteristics of peach palm fruits and seeds from the Belém hybrid population grown in Mococa, SP, in 1999.

Characteristic

Correlation coefficients $(r)^{1}$

\begin{tabular}{|c|c|c|c|c|c|c|c|c|c|c|}
\hline 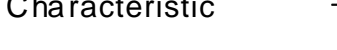 & FWIDTH & ESHAPE & LENWID & FMASS & SLENGHT & SWIDTH & SMASS & AREGRA & ACROSS & AREDIGI \\
\hline $\begin{array}{l}\text { Fruit length } \\
\text { (FLENGHT) }\end{array}$ & 0.897 & -0.444 & 0.936 & 0.848 & 0.532 & 0.534 & 0.546 & 0.869 & 0.938 & 0.884 \\
\hline Fruit width (FWIDTH) & & -0.779 & 0.982 & 0.960 & 0.750 & 0.762 & 0.760 & 0.946 & 0.979 & 0.958 \\
\hline $\begin{array}{l}\text { Fruit shape } \\
\text { (leng th/width - } \\
\text { FSHAPE) }\end{array}$ & & & -0.675 & -0.718 & -0.767 & -0.784 & -0.743 & -0.683 & -0.669 & -0.688 \\
\hline $\begin{array}{l}\text { Leng th } x \text { width } \\
\text { (LENWID) }\end{array}$ & & & & 0.975 & 0.705 & 0.713 & 0.730 & 0.957 & 0.997 & 0.972 \\
\hline Fruit mass (FMASS) & & & & & 0.746 & 0.756 & 0.792 & 0.975 & 0.972 & 0.968 \\
\hline $\begin{array}{l}\text { Seed length } \\
\text { (SLENGHT) }\end{array}$ & & & & & & 0.956 & 0.954 & 0.706 & 0.708 & 0.711 \\
\hline $\begin{array}{l}\text { Seed width } \\
\text { (SWIDTH) }\end{array}$ & & & & & & & 0.956 & 0.707 & 0.718 & 0.715 \\
\hline Seed mass (SMASS) & & & & & & & & 0.737 & 0.750 & 0.750 \\
\hline $\begin{array}{l}\text { Surface area by } \\
\text { gravimetry } \\
\text { (AREGRA) }\end{array}$ & & & & & & & & & 0.957 & 0.990 \\
\hline
\end{tabular}

Cross-sectional area

by digitalization

0.970

(ACROSS)

Surface area by

digitalization

(AREDIGI)

${ }^{1}$ All the correlation coefficients were significant at $0.01 \%$ by Pearson's method $(n-2=88)$.

Table 3 - Allometric relationships between peach palm fruit dimensions and surface area estimates in the Belém hybrid population grown in Mococa, SP, in 1999.

\begin{tabular}{llrl}
\hline Independent variable $(\mathrm{x})$ & \multicolumn{1}{c}{ Fruit surface area equation $(\mathrm{Y})$} & $\mathrm{S}$ & $\mathrm{R}^{2}(\%)$ \\
\hline Maximum fruit length $(\mathrm{cm})$ & $\mathrm{Y}=1.017\left(\mathrm{x}^{2.729}\right)$ & 10.903 & 82.50 \\
Maximum fruit width $(\mathrm{cm})$ & $\mathrm{Y}=10.908(\mathrm{x}-0.615)^{1.470}$ & 6.999 & 92.50 \\
Product length $\mathrm{x}$ width $\left(\mathrm{cm}^{2}\right)$ & $\mathrm{Y}=2.077 \times \mathrm{x}^{(1.189)}$ & 5.979 & 94.80 \\
& $\mathrm{Y}=-6.261+3.961 \times$ & 6.169 & 94.46 \\
Fruit weight $(\mathrm{g})$ & $\mathrm{Y}=4.553 \times \mathrm{x}^{(0.712)}$ & 5.772 & 95.15 \\
& $\mathrm{Y}=11.133+1.245 \mathrm{x}$ & 6.629 & 94.07 \\
Cross-sectional area $\left(\mathrm{cm}^{2}\right)$ & $\mathrm{Y}=1.867 \times{ }^{(1.297)}$ & 6.082 & 94.62 \\
& $\mathrm{Y}=-10.318+4.918 \mathrm{x}$ & 6.384 & 94.07 \\
\hline
\end{tabular}

$\mathrm{S}=$ standard deviation; $\mathrm{R}^{2}=$ determination coefficient

\section{Allometric relationships between fruit weight and surface area}

Fruit weight was also a good estimator of surface area, although this characteristic is destructive and can only be measured after fruit harvest. The exponential function was again slightly better $\left(R^{2}=95.2 \%\right)$ than the linear equation $\left(R^{2}=93.6 \%\right.$ ) (Table 3$)$, which overestimates surface area when the fruits weigh less than $9 \mathrm{~g}$. Nevertheless, the adjustment of the linear equation was good in the 10 to $80 \mathrm{~g}$ interval.

\section{Allometric relationships between fruit cross-sectional and surface areas}

In germplasm prospection and collection, the characterization of fruit size and shape is achieved by tracing the cross-sectional outline, done directly in the collection passport form, as proposed by Clement (1986a). This drawing, easily done under field conditions, allows the measurement of length and maximum width, calculation of the cross-sectional area and, through an allometric relationship, estimation of the surface area of the fruit. However, the measurement of the fruit crosssectional area is destructive, since the fruit has to be cut in half. The exponential function was slightly better $\left(R^{2}=94.6 \%\right)$ than the linear equation $\left(R^{2}=94.1 \%\right)$, although the surface area of small fruits (with cross-sectional area less than $5 \mathrm{~cm}^{2}$ ) was underestimated. 


\section{Estimates of time spend on gravimetric and digital area estimation}

Image digitalization, cutting the fruit and removing the pulp took $60 \%$ of the total time, cutting the peel and correctly positioning it in the scanner took $30 \%$, while the remaining $10 \%$ was spent on image edition and automatic area calculation. After peel preparation, the 90 fruits were digitalized and their respective areas calculated in a period of four hours, by a single person (2.66 minutes/ fruit, using a Penthium $200 \mathrm{MHz}$ personal computer with 32 Mbytes of ram memory and a table scanner setup for 300 dpi black and white image). For the gravimetric method, $50 \%$ of the time was spent on removing the pulp, $20 \%$ on peel cutting, and the remaining $30 \%$ cutting and weighing the disks. After peel preparation, the 90 fruits were processed and their respective areas calculated in a period of about eight hours, by a single person (5.35 minutes/fruit).

Besides fruit surface area estimation, the image digitalization method also provides easy quantification of damages caused by insects and/or microorganisms on the epicarp.

\section{CONCLUSIONS}

Surface area estimation by image digitalization is feasible in peach palm, with precision similar to that of the gravimetric method and twice as fast. Simple allometric relationships between non-destructive, easily measurable traits and fruit surface area provide reliable estimaton of fruit surface area. Among these, the product of length $x$ maximum width of the fruit is the simplest and most accurate. However, validation of these allometric relationships is essential when applied to other genetic materials.

\section{ACKNOWLEDGEMENTS}

To Dr. Charles R. Clement, of INPA, for suggestions on and revision of this paper.

\section{REFERENCES}

ANADARAJ, M.; BHAGAVAN, S. A simple method to determine the surface area of areca fruits (Areca catechu L.) Journal of Plantation Crops, v.11, p.165-166, 1983.
BANARAR, M.; LOWNDS, N.K.; BOSLAND, P.W. Relationship of physical properties to postharvest water loss in pepper fruits (Capsicum annuum L.) Pakistan Journal of Botany, v.26, p.321-326, 1994.

CALDAS, L.S.; BRAVO, C.; PICCOLO, H.; FARIA, C.R.S.M. Measurement of leaf area with a hand-scanner linked to a microcomputer. Revista Brasileira de Fisiologia Vegetal, v.4, p.17-20, 1992.

CLAYTON, M.; AMOS, N.D.; BANKS, N.H.; MORTON, R.H. Estimation of apple fruit surface area. New Zealand Journal of Crop and Horticultural Science, v.23, p.345-349, 1995.

CLEMENT, C.R. Bactris gasipaes; lista mínima de descriptores para el banco de germoplasma. Turrialba: CATIE; GTZ, 1986a. 15p.

CLEMENT, C.R. Descriptores mínimos para el pejibaye (Bactris gasipaes H.B.K.) y sus implicaciones filogenéticas. San José, 1986b. 216p. Escuela de Biologia, Universidad de Costa Rica. Tese (Mestrado).

DIAS-PEREZ, J.C. Transpiration rates in eggplant fruit as affected by fruit and calyx size. Postharvest Biology and Technology, v.13, p.45-49, 1998.

GALBREATH, R.A. Estimating fruit surface area. New Zealand Journal of Agricultural Research, v.19, p.543-544, 1976.

GOMES, F.P. Curso de estatística experimental. 12.ed. Piracicaba: Nobel, 1987. 467p.

HYAMS, D. CurvExpert 1.3. A comprehensive curve fitting system for Windows. Starkville, 1997. http://wwwebicom.net/ dhyams. fev. 2001.

LISTER, C.E.; LANCASTER, J.E.; SUTTON, K.H.; WALKER, J.R.L. Developmental changes in the concentration and composition of flavonoids in skin of a red an a green apple cultivar. Journal of the Science of Food and Agriculture, v.64, p.155-161, 1994

MARCELIS, L.F.M.; HOFMANEIJER, L.R.B. The contribution of fruit photosynthesis to the carbon requirement of cucumber fruits as affected by irradiance, temperature and ontogeny. Physiologia Plantarum, v.93, p.476-483, 1995

MEAH, M.B. Mode of infection of mango stem-end rot pathogen Botryodiplodia theobromae Pat. Bangladesh Journal of Botany, v.22, p.21-27, 1993.

MORA-URPÍ, J.; CLEMENT, C.R.; PATINO, V.M. Diversidad genetica en pejibaye: I. Razas e hibridos. In: CONGRESO INTERNACIONAL SOBRE BIOLOGIA, AGRONOMIA E INDUSTRIALIZACION DEL PIJUAYO, 4. Iquitos, 1993. Anais. San José: UFCR, 1993. p.11-19.

PADMANABAN, B; DANIEL, M ; JOSE, C.T. A non-destructive method to estimate surface area of areca fruit for entomological studies. Journal of Plantation Crops, v.25, p.103-105, 1997.

SCHULTZ, H.R. Grape canopy structure, light microclimate and photosynthesis. 1. A two-dimensional model of the spatial distribution of surface area densities and leaf ages in two canopy systems. Vitis, v.34, p.211-215, 1995.

TIMMER, L.W.; ZITKO, S.E.; ALBRIGO, L.G. Split applications of copper fungicides improve control of melanose on grapefruit in Florida. Plant Disease, v.82, p.983-986, 1998

YANG, Y.; ALLEN, J.C.; KNAPP, J.L.; STANSLY, P.A. An age-structured population model of citrus rust mite: a fruit-mite-fungal pathogen system Ecological Modelling, v.104, p.71-85, 1997. 